\section{Psychiatrist offered visiting post after Toronto drugs row}

David Spurgeon, Montreal

David Healy, the University of Wales psychiatrist who sued the University of Toronto, its dean of medicine and the head of one of its teaching hospitals in a dispute over academic freedom, has won an appointment as a visiting professor at the university's medical school.

Healy, who has written and lectured widely on psychological drugs, had been offered the job of clinical director of the mood and anxiety disorders programme at the university's affiliated Centre for Addiction and Mental Health (CAMH).

But the offer - which included a university professorship - was withdrawn after Healy gave a lecture at the university that was critical of 'psychotropic' drugs, including Prozac, made by Eli Lilly, which contributes funds to the CAMH (see Nature 413, 240 ; 2001).

The withdrawal resulted in a letter to the university president from 27 eminent scientists calling it "an affront to the standards of free speech and academic freedom". Healy's Can\$9.4-million (US\$6-million) lawsuit charged that the university denied him academic freedom and that he was defamed as a scientist and physician during the university's attempts to justify the job withdrawal.

The CAMH website carries a joint statement from Healy, itself and the university, saying that they are "pleased to announce the settlement of all litigation and other outstanding disputes".

"Although Dr Healy believes that his clinical appointment was rescinded because of his November 2000 speech at CAMH, Dr Healy accepts assurances that pharmaceutical companies played no role" in the reversal, the statement says.

The announcement adds that Healy will continue to write and speak on issues concerning pharmaceutical companies, research and academic freedom. Healy will visit the university for one week each year during the next three years.

Vic Catano, president of the Canadian Association of University Teachers, calls the settlement "a complete vindication for Dr Healy". www.camh.net

www.caut.ca

\title{
Spying charges dropped as Japanese biologist cuts deal
}

David Cyranoski, Tokyo

One of the two Japanese biologists facing unprecedented charges of espionage in the United States has struck a plea bargain and pleaded guilty to a less serious felony.

Hiroaki Serizawa, a molecular biologist currently at the University of Kansas, entered his plea - saying that he was guilty of making false statements to investigators - as part of a deal with prosecutors reached at the Northern District of Ohio Court on 1 May.

The deal was struck less than two weeks before Serizawa was due to go on trial accused of helping Takashi Okamoto steal DNA samples and cell lines from the Cleveland Clinic Foundation, where Okamoto worked, and transport them to Japan. Okamoto took up a post at the Institute of Physical and Chemical Research (RIKEN) in Japan in 1999.

US prosecutors have now formally asked the Japanese government to extradite Okamoto, and Serizawa appears to be ready to testify against him.

Serizawa and Okamoto were charged in May 2001 with violating the 1996 Economic Espionage Act, transporting stolen property and conspiracy (see Nature 411, 225-226; 2001). The severity of the charges caused a furore in Japan, where their actions were widely viewed as consistent with Japanese researchers' comparatively relaxed approach to the transfer of research materials.

The charge that Serizawa has admitted which is still classed as a felony - refers to statements he made about his relationship with Okamoto when he was approached by the Federal Bureau of Investigation in September 1999. As part of his bargain, Serizawa has agreed to cooperate in the case against Okamoto, who still lives in Japan, although he resigned from his position with RIKEN last summer after the charges were brought.

Serizawa now faces a fine of up to $\$ 5,000$ and possibly a prison term of not more than six

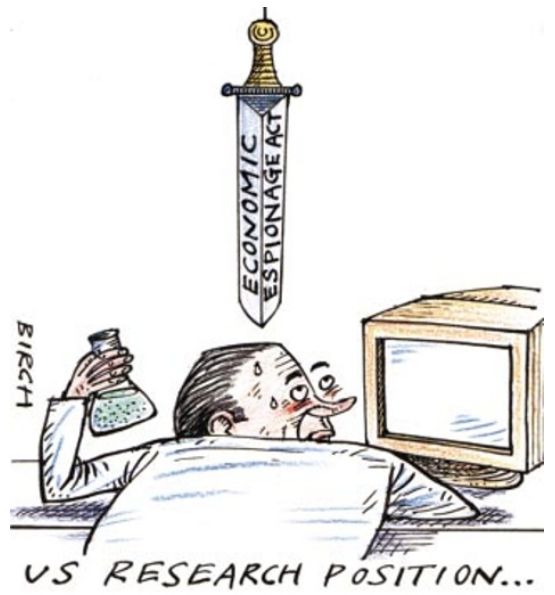

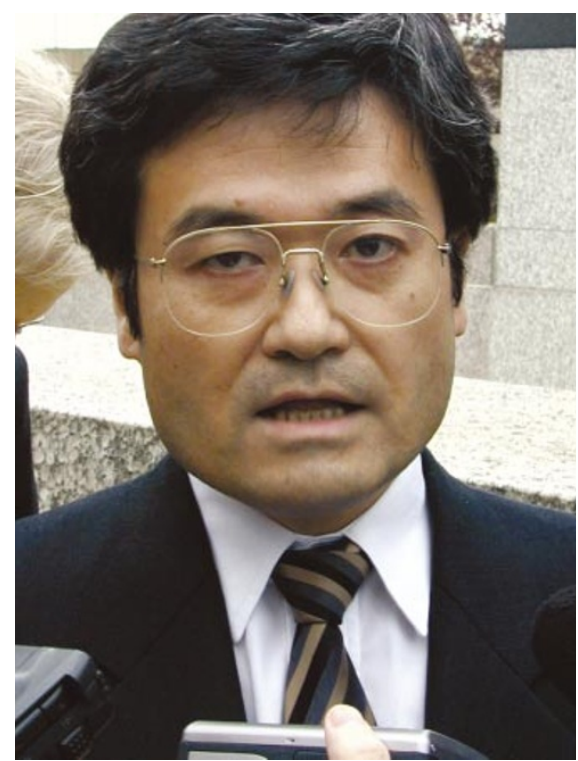

Plea bargain: Hiroaki Serizawa faces reduced charges and can stay in the United States.

months. A conviction on the original charges could have put him in jail for up to 15 years.

"The plea agreement recognizes that Serizawa did not conspire with, aid or abet Dr Okamoto in the theft of trade secrets or research materials," says John McCaffrey, one of Serizawa's lawyers. The deal allows Serizawa to stay and work in the United States, something McCaffrey says is "unprecedented" for a foreign national with a felony conviction.

But Serizawa is deeply in debt as a result of his legal bills, and his supporters say that the episode could damage him as he seeks a tenured research position. "He will have an uphill battle," says David Zapol, a researcher at Pharsight, a biotechnology company in Mountain View, California, who set up a support group for Serizawa. "He didn't deserve any of this."

US officials would not give further details of the plea bargain. "All I can say is that the original charges against Okamoto still stand and that Serizawa has agreed to cooperate in that case," says Christian Stickan, the assistant US Attorney handling the case in Ohio.

The case marks the first application of a clause in the Economic Espionage Act that expressly prohibits the stealing of trade secrets for the benefit of a foreign entity, and which some say could damage science.

"People may be wary of communicating research results as well as passing materials to colleagues," claims Joan Conaway, a molecular biologist at the Stowers Institute for Medical Research in Kansas City who supervised Serizawa's postdoctoral research. "That could have a devastating effect on research.” 